American Journal of Pharmaceutical Education 2017; 81 (5) Article 81.

\title{
COMMENTARY
}

\section{Lessons Learned on the Other Side of Campus}

\author{
Lauren S. Schlesselman, PharmD, MA Ed Psych ${ }^{\mathrm{a}, \mathrm{b}}$ \\ ${ }^{a}$ University of Connecticut Center for Excellence in Teaching and Learning, Storrs, Connecticut \\ ${ }^{\mathrm{b}}$ Associate Editor, American Journal of Pharmaceutical Education
}

Sometimes, incredible and unexpected blessings occur in our careers. Nearly a year ago an opportunity was presented to me that advanced my career in a direction I had never expected. I accepted a position as associate director at the University of Connecticut's Center for Excellence in Teaching and Learning (CETL), leaving my position as associate dean in the school of pharmacy. Since that time, I have been asked by many colleagues what lessons I can pass along from this amazing experience.

\section{Develop Transferable Skills}

Previous experiences play a role in relating to faculty across a university but well-developed transferable skills are critical when moving outside of your discipline. Regardless of the institutional setting, problem solving and a willingness to always improve one's own learning and performance influence one's ability to adapt to new situations and environments. Similarly, communication skills and ability to work collaboratively can make or break relationships while networking with schools and departments or overseeing staff. Interestingly, these are the same skills we push our students to develop. Countless students can recall my impassioned speeches about the endless options open to them with a pharmacy degree if they took the time to explore, to network, and to try new experiences. Through their exploration, networking, and experiences, they are expanding those transferable skills that will allow their continued growth. As faculty and administrators, the use of these same skills will ensure our own continued growth.

\section{Escape the Silo}

A true appreciation of siloed schools and departments can only be recognized by escaping the silo. Due to a busy workload and the tug-of-war of demands on time, faculty often do not venture out of their own departments or schools to learn what is happening across higher education. How many times have any of us heard or said, "Pharmacy is a small world"? Usually this line is stated as a warning to students to behave at a national meeting or avoid burning professional bridges. When we look at it from the higher education perspective, the small world of pharmacy can create problems.

First, we think our workload is more or of higher significance than in other disciplines. In reality, the workload can be higher and with less resources outside of pharmacy. Despite this, departments are willing to pursue new opportunities to ensure the best education is provided for students.

Second, we delude ourselves into thinking that pharmacy education has the market on innovation. In actuality, some disciplines have left pharmacy in the dust. The level of teaching innovation, even in courses with enrollments five times larger than those in pharmacy, is aweinspiring. Despite the insanely large course enrollments, faculty succeed in creating flipped, hybrid, blended, and online environments designed to maximize student learning. Advances in educational technology makes this possible for faculty willing to commit the time and passion. In a time of scare funds, departments and individual faculty are dedicating themselves to educational opportunities such as massive open online courses (MOOCs), online degree programs, non-credit certificate programs, and intersession courses in order to provide students with flexible learning and to provide their departments with income. Without taking the time to explore what other faculty are doing, the view of what is possible becomes very narrow. Make friends all over the university (or on the endless boat ride with the tune "It's a Small World" playing nonstop) who can broaden that view.

\section{Morale Can Make or Break a Department}

At CETL, nobody would dare say, "But, we have always done it this way." CETL is always looking to provide the best service to the faculty and graduate students and to keep ahead of trends in higher education. Although this can make a really exciting environment with opportunity for growth and learning, it can also create uncertainty if staff are unsure of their role in the new activities. CETL administrators work to ensure that staff are rewarded, recognized, and appreciated. Although the door is always open for staff, it is important to venture down the hallway to staff offices to have conversations. 


\section{American Journal of Pharmaceutical Education 2017; 81 (5) Article 81.}

Acknowledging birthdays or illnesses, celebrating successes, having fun, or even dedicating an entire afternoon to a single employee is essential.

On my first day at CETL, my boss was there for half the day then left for Canada to get married. With him out of the country, it was trial by fire for me to run the entire center for three weeks. At the end of the three weeks, I hosted a warm cookie party for all fifty employees to show my appreciation for "getting me through those three weeks." Yes, this takes extra time and often extra money from my own pocket, but the impact it makes on the staff morale matters.

Just as department morale can break it, so can individual morale. Change is scary. There are no guarantees that life is greener on the other side. But, as health care professionals and scientists, we know the impact of stress on health. Life as a faculty member or administrator can be insanely stressful. If you question whether the stress level in your current situation is "normal" for higher education, ask colleagues in other departments or universities. This will provide insight into normal levels of academic stress. If you reach the point that you are miserable, it is time to make a change. Your health is not worth the stress.

\section{Learn the Finance Lingo}

A few years ago, a hospital pharmacy director recommended making a business course a requirement for students enrolled in the Pharmacy LEADERS Track. As he put it, "when you sit at the table with administration to discuss budgets, you need to speak their lingo or it could cost your department millions of dollars." This applies to faculty and staff as well. Schools and departments are mini-businesses that need to establish priorities, defend resources, identify funding sources, and cultivate endowments. Without an understanding of financial lingo, kiss departmental or school funding good-bye.

\section{Appreciate Those Around You}

As long as you have taken your antihistamine today, stop and smell the roses. The true roses in our lives are those individuals who stand by us, help us grow, and brighten our day. I have always recognized that many pharmacy faculty and staff were as much family as colleagues. Now my university family has grown by leaps and bounds. As we reach the end of the semester, it is a wonderful time to take a moment to truly appreciate what those around you add to your life through mentoring and friendship.

Leaving pharmacy education to pursue advancement elsewhere in the university may not be in the cards for everyone, but that does not mean that everyone cannot continually grow as a teacher, researcher, and practitioner. So, throw open the doors, venture out into the big wide university, and shout, "Hello, world, I want to learn, grow, and be happy!" 